\title{
Students' Perception of English Learning through YouTube Application
}

\author{
Jessy Gracella ${ }^{1}$, Dedi Rahman Nur ${ }^{2}$ \\ Universitas Widya Gama Mahakam, Indonesia ${ }^{1,2}$ \\ Email Correspondence: gracellajessy@gmail.com
}

\begin{abstract}
As one of the most popular social media in this modern era, YouTube is also playing a role in education. Technology, which is part of student life, can offer useful feedback, especially in facilitating, increasing knowledge and English skills. An audio-visual model that can be accessed anywhere can make students feel more open about thoughts, opinions, questions and be more comfortable and motivated in learning English. This article reports a qualitative study that finds out students' perceptions of English learning through YouTube are beneficial and help them learn English. 5 students who use the YouTube application as a media for learning English in SMK Negeri 17 participated in this study, and data were collected through interview-based on case study design.

The results of this study find out all of the students have many benefits to improve their English skills, and very easy to access in almost every student's gadget and it can be used in every situation for help and motivated them to learn English. The students are only feeling the difficulty if the internet connection is not good.

All of the students are given positive responses about the use of YouTube application in learning English.
\end{abstract}

Keywords: Students' perception; Social Media; English learning; YouTube Application.

\begin{tabular}{|c|c|c|}
\hline$\overline{\text { DOI }}$ & : & https://doi.org/10.24903/bej.v2i1.623 \\
\hline Received & $:$ & December 2019 \\
\hline Accepted & : & January 2020 \\
\hline Published & : & February 2020 \\
\hline $\begin{array}{l}\text { Copyright and } \\
\text { License }\end{array}$ & : & $\begin{array}{l}\text { Authors retain copyright and grant the journal right of first publication with the } \\
\text { work simultaneously licensed under a Creative Commons Attribution 4.0 } \\
\text { International License that allows others to share the work with an acknowledgment of } \\
\text { the work's authorship and initial publication in this journal. }\end{array}$ \\
\hline
\end{tabular}




\section{INTRODUCTION}

In this modern era, technology becomes a part of a student's life. Social media becomes the hottest topic for discussions because it can be used for searching some sources that Indonesian society accesses the most. 97.4 percent of Indonesians have access to accounts social media [34]. The increasingly widespread use of social media sites makes it easy for people to share information, even more so with the development of smartphones in today's society.

Learning is a communication process among students, educators, and teaching materials. Communication will not work without assistance as a means of delivering messages or media. Electronic learning systems or e-learning can be used as information technology media that are applied in the field of education in the form of virtual schools. With e-learning, students do not need to sit sweetly in the classroom to listen to any congratulations from the teacher directly. E-learning can also shorten the learning target schedule, and the course alone saves costs that must be incurred by study programs or educational programs [4]. For the teenage community like students, social media is not a stranger thing for them anymore. Furthermore, Social media is recognized as learning and teaching tools. These tools facilitate discussion, participation, and the sharing of various forms of content (text, audio, video, and image). They have become an essential resource for students across all subjects, especially in learning language. YouTube is one of the social media and internet-based learning resources that can be integrated in learning that is sometimes considered difficult by students because of the burden of reading.

Moreover, YouTube is one of the most popular video sharing services on the internet today [33]. It is can use as a learning medium that presents images and sound representations of various ideas or events in the classroom. Watching videos can be another way of learning besides lecturing and reading books, because it is the expectations of internet generations who tend to demand varied learning. In addition YouTube as a social network that is being widely used today. The inclusion of YouTube in the field of education is an easy and userfriendly way to improve collaboration skills and integrate technology into teaching activities. 
YouTube also offers a learning experience with new technologies, which will be useful when they graduate [2]. The network can help create, analyze, and produce information and ideas more quickly and efficiently. Furthermore, it also provides many exciting and creative features to be used as a source of teaching and learning. By implementing learning based on the YouTube application, it can encourage students to become independent in learning, and the students will get used to thinking critically [15]. In addition, [9] stated that students will also be accustomed to searching for information from various sources to learn. Moreover, YouTube-based learning knowledge and the development of student insights can improve learning outcomes, so the implications for the quality of education will also improve.

Education is a powerful tool that can help to modify student behavior based on the needs and expectations of the community. In teaching and learning process, there are four important skills such as reading, writing, listening and speaking. Students need easier access to improve their English ability in those skills. Students' attitude is an integral part of learning and therefore must be an essential component of second learning pedagogy. If students have a positive attitude towards any subject, they can achieve many things in a specific area. There is an interaction between learning language and environmental components where students are raised. A negative and positive attitude has a strong impact on the success of language learning. [35] in [17] stated that a person's perception is an active process that plays a role, not only the stimulus that hits them but also the individual as a whole with his experiences, motivations and attitudes that are relevant in responding to stimuli. Individuals in their relationship with the outside world always make observations to be able to interpret the stimuli they receive and sense organs are used as a link between individuals and the outside world. In order for the observation process to occur, it is necessary that the object observed by the sense organs is good enough and attention is the first step as a preparation for making observations. Perception in a general sense is a person's view of something that will make a response to how someone will act. 
According to the study of [29] with the research title "Students' Perceptions toward Using YouTube in EFL Classrooms" shows the participants' perception about the implementation of YouTube is positive, and there were no students' response negative about using YouTube in EFL class. However, using YouTube at EFL classes to improve their pronunciation and motivate them to study English outside the classroom as well as to develop some level of student autonomy is still unclear. Researchers also concluded that YouTube is a useful application as media in teaching English to EFL student.

Moreover, in 2020 the Covid-19 pandemic has shaken all aspects of the world, including education. For this reason, online learning is expected to be the ultimate solution for education to continue teaching and learning. The purpose of this study is to find out students' perceptions of learning English through a YouTube application. This research conducted to find out students' views about using YouTube in learning English. Researcher chooses to analyze students in SMK Negeri 17 Samarinda because Researcher either to find out the effectiveness of YouTube Application in learning English for students in pharmacy school. From this study researcher also able to find out whether YouTube as a media source can provide language practice, increase their motivation in learning, and finds the more ways to improve them in learning English language skills in a way that attractive to students at SMK Negeri 17 Samarinda.

\section{METHODOLOGY}

This study is qualitative because intends to find out and explore students' perception of English learning through YouTube application [8]. Case studies is a research design which more focus to explore deep process of event or activity [8]. Researcher take case studies as the research design because it is the most appropriate design to find out students' perception of English learning through YouTube Application.

The researcher has been conduct this study in designated place because this study using Zoom application for interview which means researcher were not conduct this study in natural field setting such as school, classroom and research locations. The designated place was a suitable and quiet place for researcher to do interview via Zoom application. Each participant has been interviewed on line and both interviewer and interviewee had prepared themselves in an isolated and quiet environment, free from as many distractions as possible. Participants have been interviewed individually and information, responses, and observations from other participants were not shared. 
Researcher chooses 5 pharmacy's students of class XI in SMK Negeri 17 Samarinda to be research subjects. Researcher determines the sampling by specific characteristics that are appropriate to the purpose of the study so that is expected to answer the research problem. Therefore, an inclusion criteria is needed to consider the sample. These below are some criteria that were made by the researcher:

1. The students of class XI Pharmacy, TLM and DA in SMK Negeri 17 Samarinda who get a good grades predicate in English lesson.

2. Has used the YouTube application as a medium for learning English.

According to [8] purposive sampling selects individuals or groups of individuals that are especially knowledgeable about or experienced with a phenomenon of interest. Therefore, the subjects who participated in this study are those who use commonly YouTube Applications were considered for further analysis because they did use YouTube Application as tools of English learning.

For this qualitative study, Researcher used interview as the main instrument in collecting data. According to [8] qualitative researcher are the one who gather the information in collecting data by using an instrument. Researcher will make an online room via Zoom application and share the link to the interviewee for join the room and ask several of questions that will help to answer the research questions in chapter one. Researcher will ask some questions that include students' perception of English learning through YouTube application. In addition, Researcher also tap a record during the interview session to help researcher in collecting research data. Based on the statement of [7] Interviews are primarily done in qualitative research and occur when researchers ask one or more general participants, open-ended questions and record their answers. Interviews are particularly useful for uncovering the story behind a participant's experiences and pursuing in depth information around a topic. In the study of qualitative research, researcher as the primary instrument in collecting data by interview [28]. Qualitative researcher are the one who gather the information in collecting data by using an instrument of [7]. The role that researcher undertook while exploring out students' perception of English learning through YouTube application is as Zoom-researcher (Interviews by Zoom application). Researcher will make a phone call to interviewee and ask several of questions that will help to answer the research questions in chapter one. Researcher will ask some questions that include teacher's challenges in teaching English to young learners using Montessori's method. In addition, Researcher also tap a record during the interview session to help researcher in collecting research data. For 
this study, Researcher use semi-structured interview (Zoom aplication-Researcher) to find out students' perception of English learning through YouTube application. The interview is via Zoom to get more in-depth information and comfortable to interview participants to speak face to face.

Data collecting procedure based on following steps:

1. Started the interview using open-ended questions based on interview guideline.

2. Interviews the students that using YouTube as a media of learning English.

3. Taking notes during the interview session.

4. Tap audio recording during the interview session.

The analysis of interview results was carried out through [21] data analysis. In the process of reduction, the researcher will collect all informations from interview results, and audio recording of interview session via Zoom application then transform them by the process of selecting, focusing,simplifying and minimized them to complete the purpose of the research. Next in the process of data display, researcher displaying data in narrative text, therefore the result will be presented in descriptive. Lastly, researcher conclude data based on the theory and strengthened with data and detail information from the analysis of interview and recording of video as well. Researcher will revisiting the data at many times and do cross-check to verify the conclusions. Then, researcher discribing the conclusion of the study.

\section{FINDINGS}

Students' perception of English learning through YouTube application in this study was obtained from interview. This section presents 10 information of students' perception from semi structured interviews to answer research question in this study.

\subsection{The benefits that students receive after learning English using YouTube application.}

The Researcher found out all of the students are get many benefits after learning English using YouTube application. The students can understand more quickly and adding insight into learning English from various sources by watching the videos on YouTube. Because YouTube application is easy to use and the students can re-play the video until they understand "There are so many benefits; I understand more quickly, especially through videos so that I can re-play and share the videos with my friends, I can get more information, and I also get the experience of people studying abroad about the differences in the language of those who studying in another country" (Q1S1) Furthermore, student 3 said that YouTube application can improve about listening skill by watching video with subtitle "The benefit is 
that I understand better about the listening, if I watch the video, I can read the subtitles and then hear the audio how to pronounce it like that" (Q1S3). It shows that the students are got many benefits by learning English using YouTube application.

\subsection{YouTube application helps students improving their English skills in classroom and at home.}

Most of the students said that YouTube application can improve their English skills in classroom and at home. Because if anytime they are forget about the lesson in class, YouTube can help them for searching videos about learning English "Yes, it improves me, if I don't understand about the material in class so I can search through YouTube because there are many sources videos on YouTube, so I can receive more information" (Q2S3). This statement shows that YouTube application can help the students to improve their English skills in classroom and at home.

\subsection{YouTube application motivated students in learning English.}

The statements of the students are tending to be positive. Because all of the students said that was very motivated by using YouTube in learning English. "I am very motivated, because on YouTube there are many people who speak English fluently even though they are not from England, so I also motivated to be able to speak English like that." (Q3S3) This statement shows that by using YouTube could be arouse the students' motivation to speaking English fluently.

Besides, student 5 stated that "Motivated, because when I learning English on YouTube, I don't need to use a book, just have to listen and watch, so it's easy to enter in my brain." (Q3S5) It showed about how the students are motivated to learning English using YouTube Application.

\subsection{What students learn and how they learn on YouTube application.}

The answers of the students are showing their perception about what they did and how they learn English by using YouTube application. Most of the students learn about listening, speaking, pronunciation, and vocabulary "Usually about speaking, dialogue and listening to stories. I learn it by watching videos with lots of dialogue, so I can easily understand, try to apply sentences in the dialogue and listen over and over again until I understand the meaning of the sentence." (Q4S3) Besides, there is a student learning about conversation by watching video. Moreover, student 4 also stated that "I learn about vocabulary, pronunciation, British accents and slang words. And how to learn, I often watch the content creator from abroad, so there are subtitles in the video and I try to translate the meaning of 
the words by myself." (Q4S4) Based on the students' responses, there are a lot of English materials that can be seen for learning in YouTube application.

\subsection{YouTube application facilitates in learning English.}

Most of the students agreed that YouTube facilitated them in learning English. Because YouTube application is easy to access and can be found anywhere "Yes, it helps and facilitates, because it can be found anywhere. If we don't have a cellphone, we can also go to an internet cafe or from a laptop, so we just need to provide an internet connection". (Q5S1)

One of the students also stated that YouTube facilitated them during pandemic, even though they cannot go to school. "Yes, it can. Because we are currently in a pandemic so we cannot meet teachers and friends, and most people already have a cellphone so they can open videos on YouTube about material that they do not understand, such as English. (Q5S2) From this perception, showed that YouTube application could offer good feedback for students to facilitate learning English even though the students must be learning by them self at home.

\subsection{The intensity of using the YouTube application to learn English.}

The results of the interview are showed that the students have the different intensity of learning English using YouTube application. But 3 of 5 students are used YouTube application for learning since they are in Junior High School and it takes a different duration around 1 until 3 hours in a day. "It's been a while; from I'm in junior high school grade 9 when I was preparing myself for the National Examination. If I study and already understand, maybe just for a while, but if I still don't understand it can take up to 1 hour." (Q6S4) Besides, 2 of 3 students are used YouTube application since the pandemic because they cannot go to school and the must learn independent by them self. And it can take duration around 15 minutes until 2 hours in a day. "About four months since this pandemic. I usually spend 1-2 hours studying English, and I have to be able to understand, because there are many other lessons as well so I have to pursue a target to be able to understand each lesson." (Q6S2) The students' statements above are showed their intensity of learning by using YouTube application.

\subsection{The difficulty of accessing YouTube application.}

In interview, the researcher asked the students if there any difficulty to accesses YouTube application. There is 3 of 5 students are said that the difficulty is on the signal. They feel the problem on bad signal, because it would be an effect to the videos when they are learning." The signal is the most difficulty, because sometimes the signal is good but 
sometimes it's bad. If the signal is bad, the video becomes would jammed, if I lower the resolution the image is not clear. So it's hard there." (Q6S3)

In contrast, 2 of 5 students are stated that there is no difficulty because the cellphone is very supportive, and just need a Wi-Fi at home." There is no difficulty, because the cellphone is very supportive, especially if you have a laptop at home, you just need to provide the Wi-Fi, so it'll smooth." (Q6S4)

\subsection{The gadget used for learning English through YouTube application.}

In Interview, the researcher asked the students about what gadget that they used for watching the YouTube videos. Most of the students are answered that they used a Cellphone for watching the YouTube video. Because they feel it is more easy and flexible for learning using they cellphone. "I usually use my cellphone because it more easy." (Q8S3)

Furthermore, there is student that used a TV or laptop for watching the YouTube video. "Usually I access from TV or Mobile Phone, but most of the time through Mobile Phone." (Q8S2) "Usually if there is a laptop at home, I can use a laptop. But I usually use cellphone more often." (Q8S4)

From the information above, the researcher perceived that the most gadgets that they used for learning English through YouTube application is by using their cellphone.

\subsection{Various channels for learning English through YouTube application.}

The students give the different answers about the channel that they are watch for learning English. There is a student that learning vocabulary by watching a movie. The other learning about listening by listens to the music in YouTube and by a content creator.

Furthermore, 2 of 5 students are watching a specifics channel that containing an English material. "I was learning the most from 'Learn English with TV series' channel and 'English with Lucy channel.'”(Q7S4) and student 3 said that "I usually watch 'TEDx Talks', I learned more about listening from native speakers and their correct pronunciation." (Q7S3) Based on the students' responses, there is a various channel in YouTube application that can be used as a sources for learning English.

\subsection{YouTube application will be the students' media for learning English.}

In responding the last question, most of the students will continue to use YouTube application as a media for learning English. They agreed that YouTube application is easy to found in almost all the cellphones or laptop. And they can found a lot of English material in YouTube application, so it will be the students' media for fun learning English. "Sure, always because it is easy to access via cellphone or laptop, and it's fun to learn through YouTube, 
it's not boring and there are many kinds of material, and of course it's free."(Q8S4) Consequently, it can provide good feedback from students to continue learning English using the YouTube application.

\section{DISCUSSION}

Based on the interview result, all of the students are given positive responses about the use of YouTube application in learning English. The YouTube application has many functions for students. The students feel more open about their thoughts, opinions and questions, which make them more comfortable and motivated in learning English through the YouTube application. Students got many benefits after learning English by using YouTube, because according to them, the YouTube application is very easy to used and can access anywhere.

Besides, most of the students agreed that YouTube application can improved their English skills in classroom and at home. Because if anytime they are forget about the lesson in class, YouTube has many sources that can help them for searching videos about learning English. There is a various YouTube content that can be used for learning English. According to [1] the strength of YouTube is the availability of various types of videos content that can inspired. Through social media students can be more creative and independent in learning, thus the quality of students can improve, with the increase in the quality of students, the quality of education will also be better [11]. The way to trigger the quality of students in using social media is to take all advantage of communicating and sharing information through social media for the educational or learning process. Based on [16] there were 338.2 millions of people in Indonesia used mobile phones to accessed the social media. And it also related with the statements of the students that used their cellphone to watch a YouTube videos for learning.

According to the students' perception, showed that YouTube application could offer good feedback for students to facilitate learning English even though the students must be learning by them self at home. By implementing learning based on the YouTube application, students will become accustomed to think critically and encourage students to be independent students [15]. The students also stated that they are motivated to learning English using YouTube Application because they feel the fun way for learning besides lecturing and reading books. Based on [35] in [17] a person's perception is an active process that plays a role, not only the stimulus that hits them but also the individual as a whole with his experiences, motivations and attitudes that are relevant in responding to stimuli. 
Furthermore [14] states that "Motivation learning is an impetus happens in the individual for always improve certain qualities with the best effort or more than what they usually done". Besides, motivation learning is the result of brain stimulation and a person's feelings that arise which can be inferred from a perception as a source actualization process activator and driver the individual's behavior to fulfill a need for achieve their certain goals. Motivation to learn as a power thrust that allows someone managed to achieve what was desired. Someone who has motivation to learn high tend to always try achieving what is desired though experiencing obstacles and difficulties in achieve their goals.

For the effective time in learning English is more longer duration that takes to studied is better. In this case, based on the results of the interview, it can be seen by the development of learning English using the YouTube application since about a month, with duration of 15 minutes to 3 hours a day. It is also can approved by the scores of the students in English lesson subject.

Based on the explanation above, the researcher concludes that students' perceptions of learning English through YouTube application are positive to motivate and improve their English skills. According to [36] YouTube application is an effective media that can be used in improving English learning motivation. It also proved by their statement in the interview. The researcher highlights 3 English improvements of several students at SMK Negeri 17 Samarinda after using the YouTube application.

First is YouTube video as an English media to improve listening skill. According to several students 3 of 5 stated that they can improve their listening skill by watching video on YouTube. It can be used as a learning medium that presents images and sound representations of various ideas or events in the classroom. Watching videos can be another way of learning besides lecturing and reading books. This is expected to meet the expectations of internet generations who tend to demand varied learning. It is also approved by [29] students agree that learning English through YouTube is interesting and can be used as to encourage students' listening skill. Therefore, the students can use YouTube application for learning about listening, because there are so many videos contents that can help the students to improve their listening skill by watching a video anytime and everywhere.

Second is YouTube video as an English media to improve speaking skill. Most of the students are also improved their speaking skill by using YouTube application. Student 2 stated after used YouTube application it help to understand more quickly especially through videos. Because if any time the student forget about the lesson in class, they can searching a 
video about speaking and watching videos with lots of dialogue, try to practice the sentences in dialogue and re-play thus it can easily to understand.

It also approved by Muna, (2011) that has conducted a study on "Utilizing YouTube Videos to Enhance Students' Speaking Skill”. Discover the usefulness of YouTube videos from several techniques such as Pause, and Play in combination with several methods such as, drilling, which can improve students speaking skill and can be used by teachers or lecturers as one of the media in teaching and learning process, especially in teaching about speaking English. The third is YouTube video as an English media to improve vocabulary. In learning a language, vocabulary cannot be separated because a language can be formed by a combination of vocabulary to express the meaning. Therefore, it is important for students to increase their vocabulary, the YouTube application is a medium that can help students improve their English vocabulary. Based on the results of the interviews, students also learned to expand their knowledge and vocabulary so that they could communicate more clearly through the YouTube application. In addition, learning new words using YouTube is a fun activity, because it can be done just by watching videos that contain English with subtitles and trying to interpret new words that are found or not understood so that it increases the vocabulary of students. Based on [22] there are many functions that students get in using social media, students can used it to improve their vocabulary and build sentences in English.

This research is also proved by the research of [29] where it stated that students agree that learning English through YouTube is interesting, because there are many advantages over other media, it can help to encourage students' vocabulary, improve listening comprehension of students, more understandable because good pronunciation, helps improve students 'speaking skills and enhance students' thinking for learning. In this situation, learners can search for various types of English learning material with audio visual models.

Learning English with the use of technology is not something new, such as the use of the internet, especially YouTube as social media, which functions to support English language skills. YouTube can be a source of English learning and learning media that can meet the demands of the digital generation. YouTube can increase interest and support the learning styles of the digital generation. [30] also stated that using the You Tube application can make it easier for users to learn English. With the concept of autonomy which emphasizes self-awareness and independent decision-making skills, and focuses on freedom 
of learning in the form of the ability and willingness to make choices using appropriate learning strategies inside and outside the classroom.

Above all, this research future involvement purposed is also focused on students' motivation and improvement by learning English through YouTube application. Because YouTube also offers a learning experience with new technologies which will be useful when they graduate [2]. The network can help create, analyze, and produce information and ideas more easily and efficiently. In addition, it also provides many interesting and creative features to be used as a source of teaching and learning. It is will be a motivation for the students to learning and improve their English skill through YouTube application. It is also proved by their score in English lesson because learning outcomes are the results that achieved by students during the teaching and learning process. Within a certain period of time, generally learning outcomes are in the form of score (numbers) from teachers to students as an indication of the extent to which students have mastered the material they convey, usually these learning outcomes are expressed in numbers, letters, or sentences and are contained within a certain period.

\section{CONCLUSION}

Students' perceptions of English learning through YouTube application offers good feedback for students to facilitate in English learning and help the students to improve their English skills in classroom and at home. Students get various benefits after learning English through the YouTube application because YouTube has many functions, it is very easy to use and access anywhere. The students feel more open about their thoughts, opinions and questions, which make them more comfortable and motivated in learning English through the YouTube application. Besides, if anytime they are forget about the lesson in class, learners can search for various types of English learning material with audio visual models in YouTube. Due to it, can help to encourage students' vocabulary, improve listening comprehension of students, more understandable because good of pronunciation, helps improve students 'speaking skills and enhance students' thinking for learning. By implementing learning based on the YouTube application, students will become accustomed to think critically and encourage students to be independent students.

\section{REFERENCES}

[1] S. D. A. Abdullah, "Peran Hanan Attaki Dalam Membangun Persepsi Generasi Milenial Tentang Tuhan (Analisis Isi Atas Video 'Kangen' di YouTube)". Jurnal Ilmiah Mahasiswa Rausah Fikr 7(1):64-74. 2018. 
[2] A. M. Albantani, and M. Ahmad, "Musyahadat Al Fidyu: Youtube-Based Teaching and Learning of Arabic as Foreign Language (AFL).” Dinamika Ilmu. 17(2):291-308. 2017.

[3] B.I. Anoma, "Outlining as a Model of Essay Writing Instruction at Senior Secondary School.” Journal of Contemporary Educational Issues 135. 2005.

[4] R. Armaini, "Pemanfaatan Sarana Media Sosial Untuk Pembelajaran (E-Learning)." DIDIKPOS. 2019.

[5] J. W. Cresswell, and P. Clark, "Designing and Conducting Mixed Method Research" (2nd Ed.). 2nd ed. Thousand Oaks: CA: Sage. 2011.

[6] J. W. Creswell, Research Design Qualitative, Quantitative, and Mixed Methods Approaches. United Kingdom: SAGE Publications, Inc. 2009.

[7] J. W. Creswell, Educational Research: Planning, Conducting, Evaluating, Quantitative and Qualitative Research (Fourth Edition). United State of America: Pearson Education Inc. 2012.

[8] J. W. Creswell, Qualitative Inquiry and Research Design Choosing among Five Approaches. Third. United States of America: SAGE Publications Ltd. 2013.

[9] M. M. A. Ebied, S. A. A. S. Kahouf, and S. A. A. Rahman, "Effectiveness of Using YouTube in Enhance the Learning of Computer in Education Skills in Najran University.” International Interdisciplinary Journal of Education, 5(3). 2016.

[10] F. Faiqah, M. Nadjib, and A. S. Amir. "Youtube Sebagai Sarana Komunikasi Bagi Komunitas Makassarvidgram.”Jurnal Komunikasi KAREBA 5(2):259-272. 2016.

[11] A. M. Fiqri, "Pemanfaatan Media Sosial Dalam Dunia Pendidikan." Offering K-2 Sip 1. 2017.

[12] D. Hales, "An Introduction to Triangulation". UNAIDS. 2010.

[13] A. T. Haryanto, "Riset: Ada 175,2 Juta Pengguna Internet Di Indonesia." detikInet. 2020.

[14] Husdarta. Psikologi Olahraga. Bandung: Alfabeta. 2010.

[15] June, S., \&. Yaacob, A., and Y. K. Kheng.. "Assessing the Use of YouTube Videos and Interactive Activities as a Critical Thinking Stimulator for Tertiary Students: An Action Research.” International Education Studies 7(8). 2014

[16] S. Kemp, "Digital 2020: 3,8 Billion People Use Social Media". 2020.

[17] Kuntyassari, and Handayani, "Hubungan Antara Persepsi Terhadap Lingkungan Kerja Dengan Kepuasan Kerja Pada Karyawan Radio Jaringan Cipta Prima Pariwara Radionet Semarang." Proyeksi 9(2):49-60. 2014. 
[18] C. S Lee, et al. "Making Sense of Comments on YouTube Educational Videos: A SelfDirected Learning Perspective.” Online Information Review 41(5):611-625. 2017.

[19] A. Maharani, and H. Sri, “Analisis Sikap Siswa Terhadap Pembelajaran Bahasa Inggris Sebagai Bahasa Asing Di SMK Muhammadiyah 3 Palembang.” UNTIRTA 2(1). 2017.

[20] R. Mahendra, "Youtube Sebagai Media Pembelajaran.” Reseach Gate 1-3. 2020.

[21] M. B. Miles, and Huberman. Qualitative Data Analysis: A Methods Sourcebook. London: Sage Publications. 2014.

[22] J. Mismara, “Students’ Perception On Using Social Media For Learning English”. 2019.

[23] H. Mujianto, "Pemanfaatan YouTube Sebagai Media Ajar Dalam Meningkatkan Minat dan Motivasi Belajar.” Jurnal Komunikasi Hasil Pemikiran Dan Penelitian 5(1):135-59. 2019 .

[24] P.N. Howard \& M.R Parks, "Social Media and Political Change: Capacity, Constraint, and Consequence." American Behavioral Scientist 45(3). 2012.

[25] A. Padwick, "Attitudes towards English and Varieties of English in Globalizing India". 2010 .

[26] D. F. Polit, and C. T. Beck, Nursing Research: Generating and Assessing Evidence for Nursing Practice. 9th ed. edited by W. \& Wilkins. Philadelphia: Lippincott. 2012.

[27] M. A. Rahim, and Daud. "Humanities and Social Sciences." Scholars Journal of Arts 3(1B):105-9. 2015.

[28] H.J. Rubin, and I. S. Rubin, Qualitative Interviewing: The Art of Hearing Data. 3rd ed. Thousand Oaks: Sage Publications. 2012.

[29] A. Sakkira, and Jamaluddin. "Students' Perceptions toward Using YouTube in EFL Classrooms." Journal of Applied Science, Engineering, Technology, and Education 2(1). 2020.

[30] Shariff, and Shah. "Pupils' Perceptions of Using YouTube and Autonomous Learning." Scientific Research 10(13). 2019.

[31] M. M. Sirul, “Utilizing YouTube Videos to Enhance Students' Speaking Skill.” Sebelas Maret University. 2011.

[32] Slameto, "Belajar Dan Faktor-Faktor Yang Mempengaruhinya." Jakarta. 2010.

[33] C. Snelson, "YouTube across the Disciplines: A Review of Literature." MERLOT Journal of Online Learning and Teaching 7(1). 2011.

[34] Sugiharto, "Pengguna Internet Di Indonesia Didominasi Anak Muda." CNN Indonesia, October 24. 2016. 
[35] Walgito, Pengantar Psikologi Umum. Yogyakarta: Andi Offset. 2004.

[36] Yusri et al. "Efektivitas Penggunaan Media YouTube Berbasis Various Approaches Dalam Meningkatkan Motivasi Belajar Bahasa Inggris.” Eralingua: Jurnal Pendidikan Bahasa Asing Dan Sastra 2(2):77-82. 2018. 